\title{
Insight
}

\section{Discovering Resilient Pathways for South African Water Management: Two Frameworks for a Vision}

\author{
Erin L. Bohensky $^{1}$
}

\begin{abstract}
Factors that constitute resilience can themselves change over time in social-ecological systems. This poses a major challenge for understanding resilience and suggests greater investigation is needed of how social-ecological systems evolve through time and how to manage along more resilient pathways given continuous change. Resilient pathways account for the changing context of socialecological systems, such as changing management discourses and their societal inclusiveness, changing system boundaries and external connections, and lingering consequences of past management actions. In this paper I use two well-known conceptual frameworks to explore change in social-ecological systems and associated resilience in the case of water management in South Africa, which is undergoing a major transformation: (1) the conceptual framework of the Millennium Ecosystem Assessment (MA) and (2) the adaptive cycle described by Holling and others. Both frameworks, with minor adaptations, illustrate the system's shift from a centralized command-and-control style bureaucracy to a decentralized system guided by new legislation and a vision to balance efficiency, equity, and sustainability. During the former era, water managers attempted to maintain system stability and productivity through institutional and technical means that favored certain sectors of society, but resilience of the water management system declined as a result of increasingly unpopular policies and loss of ecosystem services. In using both frameworks, it becomes clear that the water management system contains two distinct social subsystems, representing South Africa's previously advantaged and disadvantaged populations, and that these do not progress through the phases of the MA framework and adaptive cycle uniformly. This implies particular challenges for achieving the water management vision: (1) the potential for management discourses to be manipulated by powerful groups, (2) equity issues that reflect new system boundaries that extend beyond South Africa's borders, and (3) past overallocation and poor management of water that make the previous level of privileges unattainable today. The South African water sector is a compelling case because of its dramatic transformation with as-yet unknown outcomes, but it presents challenges that are common among many large-scale social-ecological systems. With great international interest in operationalizing resilience definitions and frameworks, this exercise suggests the need to revisit definitions, continue applying these frameworks, and adapting them to capture variations in social-ecological systems.
\end{abstract}

Key Words: adaptive cycle; Millennium Ecosystem Assessment; resilience; resilient pathways; South Africa; water management.

\section{RESILIENCE IN SOCIAL-ECOLOGICAL SYSTEMS: A MOVING TARGET?}

Increasingly, the success of management regimes for social-ecological systems (Berkes et al. 2003) is seen to hinge on the maintenance or enhancement of resilience (Allison and Hobbs 2004, Ludwig and Stafford-Smith 2005). Resilience has multiple meanings, but is used here to refer to the ability of a social-ecological system (SES) to retain its essential structure and function in the face of disturbance or change (Walker et al. 2006). This may be expressed in terms of identity, meaning the system's critical components, the relationships between components in space and time, and the innovation or self-organization that maintain them (Cumming et al. 2005), or in terms of ecosystem services the system provides (Walker et al. 2002). Resilient systems tend to be flexible, selforganizing, rather than controlled by external 
forces, and can build the capacity to learn and adapt (Carpenter et al. 2001).

Social-ecological systems can shift over time between alternative configurations that provide different combinations of ecosystem services; a lake in a eutrophic state may offer nearby communities the service of waste disposal for agricultural runoff, whereas an oligotrophic lake may offer the services of recreation and a domestic water supply that requires little treatment. It therefore may be more useful to view resilience as a property of a particular system configuration rather than of the system itself (Carpenter et al. 2001). Disturbance and change can result in abrupt, nonlinear shifts that move the system past a threshold and into a new configuration in which services can no longer be provided at previous levels (MA 2005). Such shifts have been demonstrated in numerous empirical studies of different systems and management regimes (Scheffer et al. 2001, Walker and Meyers 2004).

Because such changes may be driven by slow variables (Carpenter and Turner 2001), they are often not observable within typical decision-making timeframes. Studies of resilience that appropriate a deep time perspective that incorporates a system's past, present, and future are therefore of interest in social-ecological systems research (van der Leeuw and Aschan-Leygonie 2001, Redman and Kinzig 2003). More often the problems of interest in socialecological systems have only a relatively short actual or recorded history, but even when data spanning only a decade or two are available, they may reveal the changing social contexts for managing social-ecological systems (Bohensky and Lynam 2005). For example, many societies have risen to power by pursuing unsustainable strategies, and although they believed their actions to be justifiable to achieve their goals, in retrospect these societies are seen to have eroded their resilience to forces that ultimately brought them to collapse (Janssen et al. 2003, Redman and Kinzig 2003).

The fact that both ecosystems and societal values change makes resilience something of a moving target. Given the dynamic properties of socialecological systems and the frequent need for managers to act quickly but with recognition that societal perceptions and values may change in the future, the concept of "resilient pathways" (Walker et al. 2002) may offer a useful metaphor for understanding and managing to enhance resilience. Walker and colleagues propose that "pathways that are robust to ambiguous and unforeseeable changes suggest actions that can be taken to increase the resilience of a given SES." Resilient pathways, they suggest, can be identified through a participatory management approach that is both future-oriented and adaptive.

So what would a resilient pathway look like? The "moving target" nature of resilience means that the whole context for defining resilience in an SES can change over time. Resilient pathways need to account for aspects of this changing context such as:

- Changing discourses and their inclusiveness. The sanctioned discourse (Turton and Meissner 2002), or prevailing paradigm used to justify resource management decisions, and changes in the control of this discourse over time (Pritchard and Sanderson 2002), matters for the pathway chosen. The discourse that suggests resources are best managed by a centralized bureaucracy, for example, may be popular at an early point in the SES trajectory but rejected later in time. A resilient pathway for a SES would acknowledge changing circumstances and opinion, and would allow the wide range of perspectives found within it to be acknowledged, even though some may challenge the dominant discourse. This is important to consider in largescale SES, which often contain multiple and diverse communities who hold different views, increasing potential for disagreement or conflict.

- Changing system boundaries and external connections. SES boundaries are typically defined along ecological transitions, e.g., a catchment, social ones, e.g., a community, or a combination of the two. However, these boundaries can be altered by system processes or management changes, such as rezoning of a protected area, expansion of agricultural or urban land, or interbasin transfers of water. Sometimes changing system boundaries are accompanied by an increase in connections to external systems, through exchange or trade of products, or movement of organisms, including people. A resilient pathway for an SES entails management at the scale needed to accommodate system boundaries and connections, and to avoid the mismatches 
between ecosystems and institutions that have been frequently identified as contributing to management failure (Wilson et al. 1999, Kalikoski et al. 2002, Cash et al. 2006, Cumming et al. 2006, Wilson 2006, Folke et al. 2007).

- $\quad$ Lingering consequences of past management actions. At any given point in an SES's trajectory, managers rarely have a clean slate to work upon because of the legacy effects, including perceptions, of past management actions. Resilient pathways enable learning from previous experience so that mistakes are not repeated, and making decisions now that have the best chance of maintaining future options. A resilient pathway can be likened to a road map for the future, to assist managers to act expediently but thoughtfully in a context of uncertainty. The concept of resilient pathways complements adaptive management practices, but extends beyond adaptive management in its consideration of the forces that underpin change and adaptation on broad societal scales.

These three aspects of the changing context of a SES reflect, respectively, changes in: (1) internal power dynamics within the system, (2) relationships between the system and the outside world, and the (3) flexibility of the system in terms of available options. All are likely to influence the resilience of a SES's pathway, although it should be noted that there may be other aspects of contextual change related to long-term SES resilience that are also important in some systems.

In this paper, I evaluate the extent to which two frameworks that have maintained a strong presence in SES research in recent years can assist the discovery of resilient pathways. The first is the conceptual framework of the Millennium Ecosystem Assessment, an effort to provide decision-makers with information about interactions between ecosystem services, biodiversity, human well-being, drivers of change, and possible interventions (MA 2005). The second is the adaptive cycle and panarchy model described by Holling (1986, 1987, 2001), which seek to explain the source and role of transforming change in social-ecological systems (Gunderson and Holling 2002).

I explore these frameworks with the example of water management in South Africa. The need to understand resilience as it relates to water management systems is recognized as critically important (Falkenmark 2003, Folke 2003, Moench 2005), and South Africa is a particularly interesting case, as its water sector is undergoing a significant transformation and striving to implement new water legislation supported by a mutual vision (MacKay et al. 2003). Both frameworks are to some extent already informing water policy and policy-relevant research in South Africa (see Palmer 1999, Rogers and Biggs 1999, Rogers et al. 2000, Turton and Henwood 2002, Biggs and Rogers 2003, Nel et al. 2004, Turton et al. 2005, King and Brown 2006) though mostly in a piecemeal and ad-hoc rather than an integrated fashion, and the opportunity to bring resilience theory to bear on water management remains strong.

Below I describe the evolution of water management in South Africa to date. I then explore the two frameworks and how they may help define resilient pathways for achieving South Africa's overarching water management vision.

\section{THE EVOLUTION OF WATER MANAGEMENT IN SOUTH AFRICA}

Because of the influence of political drivers on South African water management during the past $150 \mathrm{yr}$, though operating in concert with social, economic, cultural, climatic, and biophysical drivers, it is useful as a point of a departure to delineate the social-ecological system (SES) by its political boundaries, i.e., the Republic of South Africa. This SES comprises water resources, communities, and institutions that use and manage them, and the ecosystems and biodiversity associated with them. The dominant approach to manage water during this period has largely contradicted this view. Historically, South African water management has been challenged by a semiarid climate and the location of mineral deposits which encouraged settlement far from major water sources (Basson et al. 1997).

Water management became increasingly complex as the relationship between people and water changed (Turton and Meissner 2002) and human populations and their aspirations for water use grew (Table 1). For much of this period, water management was centralized, run by a bureaucracy, and favored the agricultural and industrial sectors. With South Africa's enactment of apartheid 
legislation and its subsequent political and economic isolation from much of the rest of the world, agricultural self-sufficiency, and restriction of capital outflows became major national priorities (WCD 2000). This agenda was achieved with increasingly costly technical interventions such as dams and diversions, subsidies for commercial agriculture, and an inexpensive labor supply made possible by the apartheid system. Two communities were clearly distinguished by this system: those with rights to water and those without. Water rights belonged exclusively to land-owning, i.e., white individuals, whereas non-white individuals were restricted to certain areas, typically of higher aridity, lower productivity, and lacking in formal water services (Turton and Meissner 2002). These policies tended to discourage sustainable water use, but managers took little notice because of the faith they placed in their command-and-control approach (Rogers et al. 2000).

Although the negative ecological consequences of this approach, such as altered flow regimes and degradation, became increasingly apparent (MacKay et al. 2003), broader political change was required to create an opportunity for water reform. In the years that followed South Africa's democratic elections in 1994, the National Water Act No. 36 of 1998 was penned to dramatically change water management. Founded on the principles of efficiency, equity, and sustainability, the act defines water for basic human needs and for the maintenance of environmental sustainability as rights, and promotes economic efficiency of water use through charges for water provision (DWAF $2004 a$ ). The Act enforces a "Reserve" that sets water aside for the purposes of meeting basic human and ecosystem needs. Critically, the law devolves management of water to new institutions at the catchment level, called Catchment Management Agencies (CMAs). Although the CMAs are the pivotal institutional entity in the new water management framework, they work with local Catchment Management Committees and stakeholder organizations, which guide the process within each catchment to decide the desired balance between protection and use of water resources and to establish a course of action to achieve this. CMAs are also subordinate to the national ministry, which retain certain functions.

At present, South African water management sits on the brink of a major transformation. The new policies enable water users and managers to collectively decide how to reap the multiple benefits of water, asking them to carefully define their objectives for the systems in which they live and how they will get there. However, they are faced with the formidable task of striking a balance between social equity and ecological sustainability: some $5 \times 10^{6}$ South Africans, i.e., nearly $10 \%$ of the total population, still lack access to a safe and reliable water supply and another $15 \times 10^{6}$ lack adequate sanitation (DWAF 2007), whereas freshwater biodiversity is considered transformed in $26 \%$ of the country's mainstem rivers to the point that rehabilitation is no longer possible ( Nel et al. 2004). The pathway forward depends to a large degree on the capacity of water users, managers, and institutions to plot a sustainable course to govern resources in the coming years, based on a mutual vision of the future (Rogers and Biggs 1999).

\section{TWO FRAMEWORKS}

\section{Millennium Ecosystem Assessment}

The Millennium Ecosystem Assessment (MA) was a 4-yr international work program to bring scientific information about the relationships between ecosystems and human well-being to decision makers in government, academic and research institutions, communities, and private industry (MA 2005). The conceptual framework that guided the program describes relationships between indirect and direct drivers of ecosystem change, ecosystem services, biodiversity, and human well-being. Indirect drivers include demographics, economy, institutions, technology, and culture and religion. These can affect human well-being directly or indirectly via direct drivers, which include environmental processes such as land use, hydrological modification, and species introductions, which in turn affect ecosystem services. Ecosystem services may be described as (1) provisioning services, or tangible benefits are obtained from ecosystems such as water, food, timber, and fiber; (2) regulating services that regulate ecosystem processes such as climate, water quality, and air; (3) supporting services, which include processes such as soil formation, photosynthesis, and nutrient cycling; and (4) cultural services that provide recreational, aesthetic, or spiritual benefits. Biodiversity underpins ecosystem service provision (MA 2003). 
Table 1. Water management in South Africa: a timeline of events. Sources: Herold et al. 1992, Chutter et al. 1996, World Commission on Dams 2000, World Resources Institute (WRI) 2000, Thompson et al. 2001, Turton and Meissner 2003, DWAF 2003, Metsi Consultants 2002, Myburgh and Nevill 2003. Flow is based on annual flow records from 1935-1997; mean flow for period was $6980 \times 10^{6} \mathrm{~m}^{3}$;

\section{Year(s) Event}

1800s Korana people farm on Gariep (Orange) River banks; Europeans settlers build irrigation scheme at Upington

1820-1870 A large influx of settlers from around the world introduces 11 of the 12 invasive species that now cause the greatest problems in fynbos biome

1872 First dam constructed in Gariep Basin

1880 Gold discovered in Johannesburg; water demands rise throughout surrounding Witwatersrand region

1880s-1- Botanists begin to note the spread of nonnative plants over mountain slopes and losses of endemic species in 890 s fynbos vegetation, while foresters promote mountain plantations of nonnative trees

1895 All major Witwatersrand aquifers tapped; Johannesburg experiences water shortages

1903 Rand Water Board established

1912 Passage of South Africa's Irrigation and Conservation of Water Act lays foundation for future water allocation, reserving surplus water for private property owners and establishing irrigation boards

1920s Controversy about effects of forest plantations on water supplies begins; demand for commercial timber products will drive high rates of afforestation with non-native hardwoods for next $60 \mathrm{yr}$

1928 Department of Irrigation dismisses proposed Orange River Development Project as too costly

1937 Passage of the Weeds Act; poor enforcement due to lack of field staff and resources

1935 Salinity levels in Vaal Dam begin to increase due to increasing industrial activities

1943 Annual flow of Gariep River reaches 62-yr high of 25,472 × $10 \mathrm{~m}^{3}$

1948 Nationalist Party comes into power and begins enacting apartheid legislation

1949 Purification works built to clean or divert highly saline water in the Vaal catchment

1940s-1- Hydrological studies show that plantations have a negative effect on streamflow; efforts to control invasives are 970s launched, but are uncoordinated, erratic, and hampered by limited follow-up clearing

1950s First survey of Basutoland (now Lesotho)'s water resources undertaken to assess viability of water exportation to South Africa

1956 South Africa passes Water Act no. 54 to accommodate needs of industrial expansion

1962-3 Political climate enables Orange River Development Project to win approval; poor planning results in delays and a quadrupling of initial budget

1965 Marked acceleration of Vaal Dam salinization

1970s Blackfly (Simulium chutteri) acquires pest status along Vaal, Gariep, and Great Fish Rivers after completion of Bloemhof, Gariep, Van der Kloof Dams, and Orange-Fish Tunnel. 
1970 Mountain Catchment Act passed, giving responsibility for high-lying catchments to Department of Forestry; alien plants are cleared from tens of thousands of ha

1971 Gariep Dam completed; storage capacity (5341 million cubic metres) equal to roughly one-third of Gariep basin's total runoff

1971 Water Research Commission created to initiate and fund water management research projects

1975 Orange-Fish Tunnel begins delivering water from Gariep River to Eastern Cape Province

1978 Vanderkloof Dam completed, the highest (108m) in South Africa

1986 Treaty signed to implement Lesotho Highlands Water Project (LHWP) after 8 yr of negotiations

Late-1980s Mountain catchment management responsibility passed from Department of Forestry to provinces; lack of funding hampers integrated invasive plant control programs and plants re-invade cleared areas

1992 Annual flow of Gariep River reaches 62-yr low of $818 \times 10 \mathrm{~m}^{3}$

1995 DWAF minister Kader Asmal founds Working for Water Programme, which hires 7000 people and clears 33,000 ha in its first $8 \mathrm{mo}$

1995 Katse Dam, the highest in Africa at 185 m, is completed in the Lesotho's Maloti Mountains

1998 South Africa's Water Act no. 36 declares adequate water a basic human and environmental right

1998 LHWP completed; first LHWP water is released

2004 National Water Resources Strategy completed, paving the way for Water Act implementation; first proposals to establish Catchment Management Agencies completed

2005 Olifants River stops flowing into lower reaches for first time in recorded history, threatening biodiversity in downstream Kruger National Park

The MA also defined five constituents of human well-being: basic material for a good life, health, good social relations, security, and freedom of choice and action (MA 2005). Human well-being is influenced by both ecosystem services and drivers of change, and may have feedbacks on indirect drivers, such as when health problems burden a national economy. Within the framework there are opportunities for responses, or strategies and interventions that can halt, reverse, or otherwise change a process in order to enhance human wellbeing and conserve ecosystems. The interactions depicted by the framework occur at and across various spatial and temporal scales. The MA did not focus explicitly on resilience, but its framework is built around a complex of social-ecological system relationships between drivers that influence ecosystem services and human well-being, human interventions in the system, and feedbacks. The MA suggests that the resilience of ecosystem services, and hence of human well-being, is viewed as fundamentally linked to biodiversity, and that resilience of social-ecological systems is enhanced by adaptive capacity and institutional arrangements (MA 2005).

In Fig. 1, the MA framework is populated with the South African water example. For the sake of simplicity and clarity, only the dynamics that are thought to be most relevant to the national water management system are included. Because water management today is significantly shaped by numerous events and processes that have occurred during the past century, two iterations of the framework are shown, each of which depicts a distinct era of water management.

In the first iteration, the apartheid regime and its policies, together with the economic climate, i.e., indirect drivers of change, encourage the building of large dams and other infrastructure in support of commercial agriculture, i.e., direct drivers of 
Fig. 1. Adaptation of the Millenium Ecosystem Assessment conceptual framework (MA 2005) to depict two eras of South African water management.

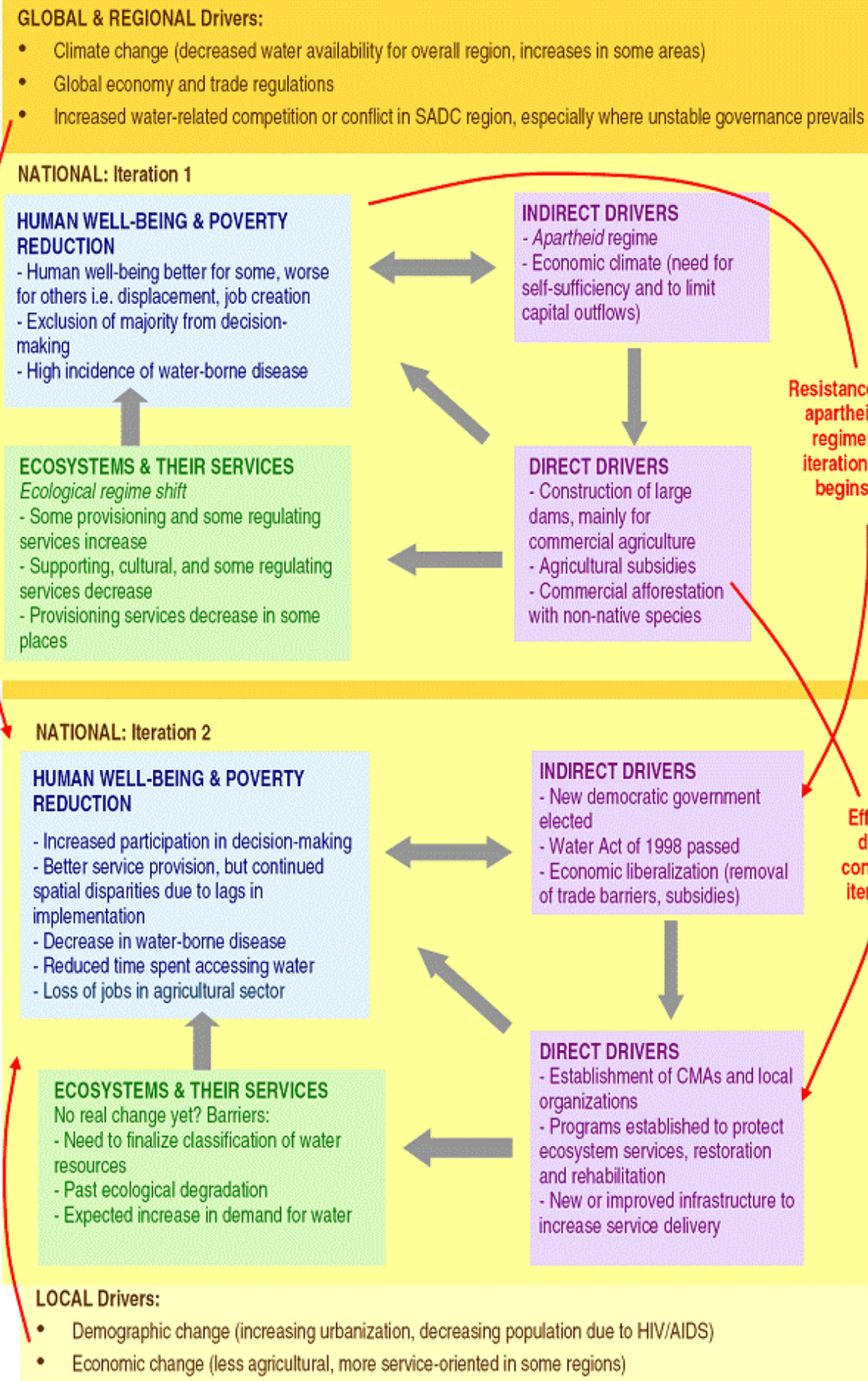

- Climate change (decreased water availability for overall region, increases in some areas)

- Global economy and trade regulations

- Increased water-related competition or conflict in SADC region, especially where unstable governance prevails

ECOSYSTEMS \& THEIR SERVICES

Ecological regime shift

- Some provisioning and some regulating services increase

- Supporting, cultural, and some regulating services decrease

- Provisioning services decrease in some places

NATIONAL: Iteration 2

\section{HUMAN WELL-BEING \& POVERTY} REDUCTION

- Increased participation in decision-making

- Better service provision, but continued spatial disparities due to lags in

implementation

- Decrease in water-borne disease

- Reduced time spent accessing water

- Loss of jobs in agricultural sector

\section{ECOSYSTEMS \& THEIR SERVICES \\ No real change yet? Barriers: \\ - Need to finalize classification of water resources \\ - Past ecological degradation \\ - Expected increase in demand for water}

capital outflows

DIRECT DRIVERS

- Construction of large dams, mainly for commercial agriculture

- Agricultural subsidies - Commercial afforestation with non-native species

LOCAL Drivers:

- Demographic change (increasing urbanization, decreasing population due to HIV/AIDS)

- Economic change (less agricultural, more service-oriented in some regions) 
change. Water management through this approach tends to improve access to a range of provisioning ecosystem services including freshwater, food, and timber, as well as regulating services such as protection against drought and floods, and dilution of pollutants. However, these benefits are captured mainly by the agricultural and industrial sectors and privileged socioeconomic groups (WCD 2000). Furthermore, in more modified catchments, these improvements often come at the expense of supporting services, such as in-stream flows for native aquatic biota (Chutter et al. 1996, Snaddon et al. 1998), and cultural services, including values placed on certain sites and cultural use of and information about ecosystems (Thabane 2000, WCD 2000).

Over time, the ecological change that results from this infrastructure development undermines some of the benefits that this infrastructure was originally intended to secure. For example, the building of the Orange River Development Project in the 1960s improves water availability for the commercial farming sector, but alters river flows so drastically that a prolific pest blackfly (Simulium chutteri) invades a large section of river used by livestock farmers, and requires significant ongoing investment in mitigation (Myburgh and Nevill 2003). During this time, increasing demand for timber drives the commercial planting of non-native tree species in mountain catchments, reducing streamflow (Görgens and van Wilgen 2004) and facilitates the spread of non-commercial invasive alien plant species (Le Maitre et al. 2004). The effects of these changes on human well-being are mixed; for example, the dam projects displace some communities but commercial farms are a major source of employment in rural areas (MacKay 2003).

The transition from the first to second era comes about as part of the growing internal and external resistance to apartheid and its economic, social, and environmental consequences (MacKay 2003). In the second iteration, the nature of drivers shifts to some degree from technical responses aimed at supporting commercial agriculture and industry to a broader, integrative approach that makes legal provision for the satisfaction of basic human and ecological needs and creates new institutions. Since this era is currently in progress, it is difficult to assess the effects of this new management approach on ecosystem services. Some measures with simultaneous benefits for ecosystem services and human well-being are evident, however, such as the multi-agency Working for Water Programme to eradicate invasive alien plants while creating employment (Görgens and van Wilgen 2004). Human well-being is expected to improve in time from the policy changes, particularly through increased access to water supplies (DWAF 2004b) and participatory decision-making, but actual reform has been slow (Seetal 2005). Gains may also be offset by the past erosion of ecological integrity and consequences for current and future human well-being, though thus far not well documented or understood. Additionally, the new water management policies eliminate subsidies for large commercial agricultural water users with the aim of internalizing some of the high costs of agriculture that were previously passed on to society and ecosystems. To some extent, this has been met with resistance, as it is seen to threaten the economic viability of this sector (MacKay 2003) and socioeconomic stability for rural society (Seetal 2005).

To indicate the continuation of the cycle over time, the framework is amended with the addition of an arrow from the human-well being box in the first iteration to the indirect drivers box in the second iteration. Although indirect drivers change from the first era to the second, some of the direct drivers that operate in the first era, such as investment in infrastructure to support supply-side water management, continue to operate in the present and are expected to form part of the national water supply strategy for the foreseeable future (DWAF $2004 a$ ). A second arrow is inserted to show the continued influence of the first-iteration direct drivers in the second iteration.

In addition, because water management at the national scale is now linked to processes at global, regional, and local scales, the main drivers at these scales are identified in boxes above and below the national-scale dynamics. Arrows from the global and regional drivers and local drivers boxes to the second iteration of the national-scale dynamics indicate emergence of cross-scale links in water managers' and public consciousness.

The population of the MA framework also reveals that improvements in ecosystem services and human well-being are not always synergistic; more often there are trade-offs, often benefiting a particular region, industry, or population over another. A further adaptation (not shown) would allow a clearer distinction of actual or potential 
trade-offs between ecosystem services or constituents of human well-being. For example, if large dams are identified as a direct driver, one might identify two distinct consequences for ecosystem services: improved freshwater access and biodiversity loss.

\section{Panarchy}

Panarchy describes a theory of complex system dynamics, with the adaptive cycle as its central feature (Holling 1986, 1987, 2001, Holling and Gunderson 2002). The cycle includes four phases or ecosystem functions: growth or exploitation, denoted by $r$, in which recently disturbed areas are rapidly colonized; conservation $(\mathrm{K})$, in which energy and material are slowly accumulated and stored; release or collapse $(\Omega)$, in which the tightly bound accumulation of biomass becomes increasingly fragile until it is suddenly released by external agents; and reorganization $(\alpha)$, in which resources are reconfigured to take advantage of new opportunities. Although these phases were originally described in reference to ecosystems, they also apply to social or social-ecological systems, which likewise progress through phases of growth, conservation, release, and reorganization (Redman and Kinzig 2003). The adaptive cycle and panarchy concepts have been expanded upon and adapted by contributors to Gunderson and Holling's edited volume Panarchy (2002) and this journal (in addition to Redman and Kinzig 2003, see Allison and Hobbs 2004, Cumming and Collier 2005), among others (e.g., Peterson 2000, Wolfenden et al. 2007) in order to explore the framework's applicability outside the strictly ecological domain.

The cycle can be illustrated as a heuristic model represented as a figure of eight in two-dimensional space, with connectedness and potential defining each axis (Holling and Gunderson 2002). Connectedness refers to the strength of internal links or relationships that mediate external variability. A certain amount of connectedness has advantages, for example, in the form of social networks (Tompkins and Adger 2004), but it is possible for a system to become overconnected, which can reduce novelty and increase system rigidity (Newman and Dale 2005). Potential means the capability for change through accumulated ecological, social, or economic resources. The speed of transition between phases varies; the model suggests that the system moves quickly from exploitation to conservation, and more slowly from conservation to release and from release to reorganization. At this point, the system may exit from the cycle and enter a second iteration as an alternatively configured system (Holling 1986). The cycle then begins again. Panarchy refers to a series of linked, often nested cycles that evolve through space and time (Holling et al. 2002).

In Fig. 2, two eras of South African water management example are illustrated with the panarchy model. The first depicts the previous command-and-control era of management, which has completed one full phase of the adaptive cycle. During the exploitation phase, increasing investment is made in large infrastructure, increasing system potential and physical connectedness. This leads to greater management rigidity and reduced ecosystem variability (Rogers et al. 2000), but allows water provision and food production to increase at a national level. Forces largely external or peripheral to the water management system, in the form of social discontent, economic decline, and political pressure, eventually lead to the collapse of the apartheid government. The transition from collapse to reorganization happens rapidly, contrary to what the panarchy model suggests. As the system reorganizes, old water laws are repealed and an extensive consultation process commences to draft new laws. However, the pace of change on the ground does not mirror that of the official legislative change, largely due to complexities in the process of institutional reform (Pollard and du Toit 2005). The communities that were disadvantaged under the previous system remain the most affected, as they await the most significant positive changes.

The second iteration of the cycle begins. At this point in time, the system undergoes a paradigm shift but only a partial change in configuration: the system is reorganizing, but is saddled with the baggage of the past era's high-cost responses, e.g., large dams, interbasin transfers, invasive species, and pollution, that limit flexibility in achieving the Water Act's efficiency, equity, and sustainability principles. The system has endured some partial crises and collapses, such as the Simulium outbreak on the lower Orange River, periodic drought, and salinization. At a national level, however, there has apparently been sufficient ecological and social resilience in the water management system to buffer the effects of disturbance, thus far. 
Fig. 2. Adaptation of the adaptive cycle (Holling and Gunderson 2002) to depict two eras of South African water management.

Iteration 1

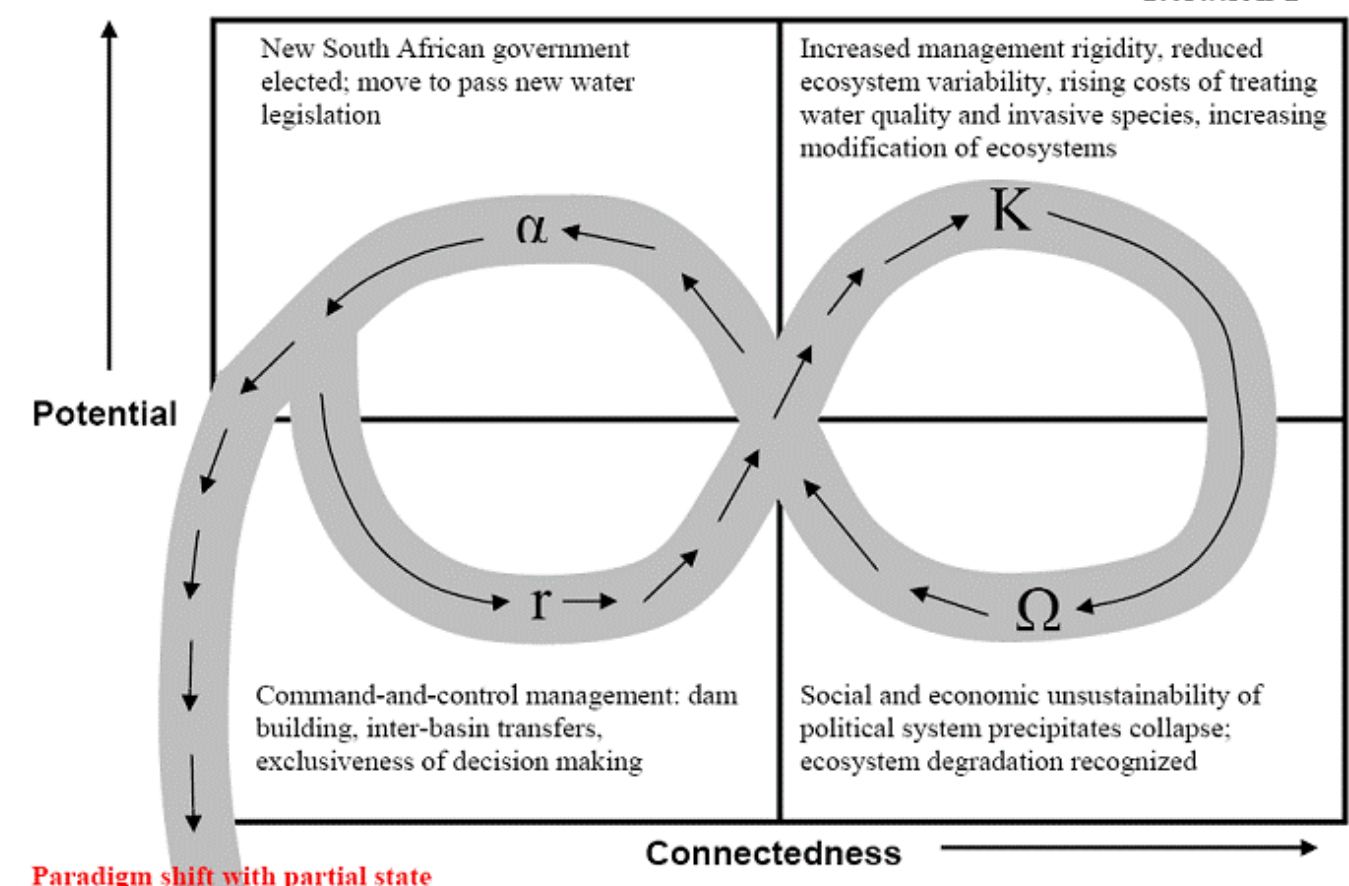

'flip'; some aspects of previous era's

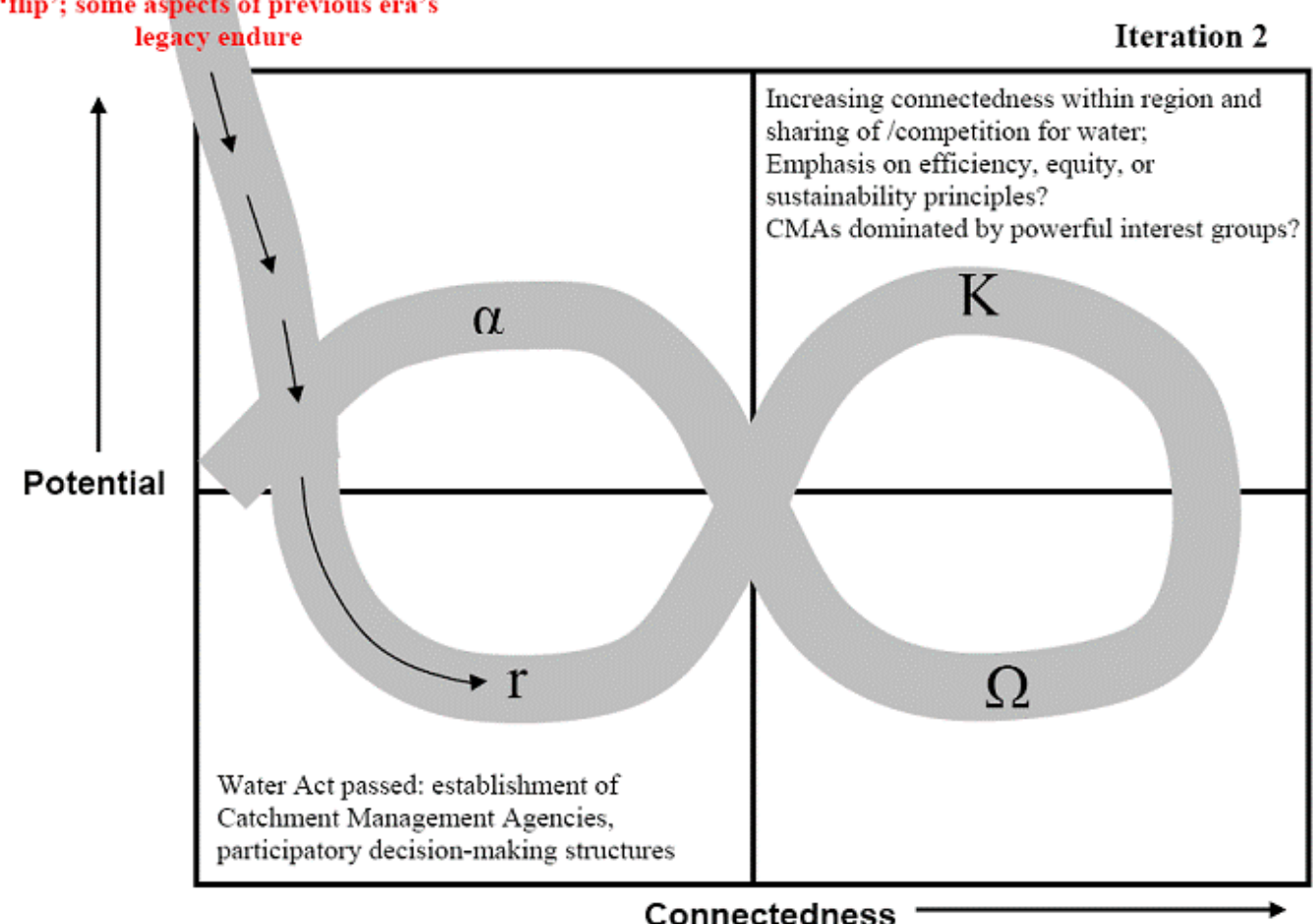


As water management moves into the second iteration, both biophysical and social-ecological connectedness within the system increases. With groundwater becoming an increasingly important resource in many areas, over-abstraction may deplete surface water (Haupt 2001). There are also increasing water-atmosphere connections; in the Vaal catchment, salinity problems, initially a result of industrial discharge into water sources, are believed to have increased due to atmospheric deposition from the area's power plants and other industries (Herold et al. 1992).

Connectedness of the social-ecological system begins to extend beyond the system boundaries. The South African economy becomes highly dependent on inter-basin transfers. In Gauteng Province, where the majority of South Africa's wealth is generated, all economically productive water is transferred from catchments outside the province (Basson et al. 1997). Most of this water, in fact, comes from neighboring Lesotho through a multi-billion dollar water project (Metsi Consultants 2002). International water sharing projects such as this point to a need for regional institutions to allocate water (Turton 2003). These projects and institutions do not merely connect distinct regions, but in fact alter system boundaries.

The likelihood of the new Catchment Management Agencies (CMA)s to mediate this connectedness is unclear. The devolution of water management functions to CMAs is intended to provide insurance against over-connectedness, as each develops its own style of governance in its Water Management Area. However, there is a danger that some CMAs may be dominated by powerful interests (Chikozho 2005), both within and external to the WMA boundaries. The new institutions may lack capacity to carry out their functions (Pollard and du Toit 2005), or may revert to the old practices of the Department of Water Affairs and Forestry in which they simply become regional extensions of the national department rather than reasonably autonomous entities (Dent 2005). In the interim period while CMAs are established, there may be a danger of non-action. In 2005 this happened in the Kruger National Park, where a major river ceased flowing for the first time in recorded history due to the combined effects of drought and the lack of a legal recourse to manage unexpected shortfalls (Biggs, personal communication, Macleod 2006). This may hint at overconnectedness in some parts of the system, i.e., between powerful water use sectors and water management authorities, but inadequate connections in others, i.e., weaker sectors lack a backup mechanism to avert such crises.

\section{DISCUSSION: ACHIEVING THE VISION}

The South African water management vision is a widely defined conceptualization of how water will be managed in accordance with the South African Water Act and its principles. Such a vision is expected to be achieved through the integration of social values, scientific knowledge, and management experience in a multi-party system (Rogers and Bestbier 1997, Rogers and Biggs 1999).

How can the above analysis inform the vision? It shows that although the water management system is clearly in a transition with an as-yet unknown outcome, it is possible to understand what has made the system more or less resilient at different points on its past trajectory, and to subsequently enhance its future resilience. The Millennium Ecosystem Assessment (MA) framework enables us to identify the drivers of change in the previous era: apartheid policies were indirect drivers of water management, directly resulting in large dam projects and encouragement of unsustainable land and water use. The adaptive cycle suggests that the system's potential increased during this era, as did connectedness within the system. It appears that the system's resilience is likely to have resided in the existing power structures, technical infrastructure, legal framework of apartheid, subsidies for agriculture, and continued delivery of a particular bundle of ecosystem services for the benefit of the minority population who supported the political regime, all of which reinforced one another to a large extent. On the other hand, some aspects of the system's resilience were not considered desirable to most South Africans nor to the rest of the world, and the unpopularity of the regime and international economic sanctions against it eventually led to its demise. Ecological resilience, and with it some ecosystem services, gradually declined. However, the largescale interventions in South Africa's water supply and investments in expensive water quality treatment schemes maintained a sufficient level of ecosystem services and human well-being to create an illusion of a well-functioning system, at least for those who controlled it. Often such water users, if their livelihoods were not directly dependent on water, were not aware of the great distances over 
which their water traveled to reach them (Snaddon et al. 1998).

In the current era, management is guided by the Water Act and its three principles of efficiency, equity, and sustainability: it will attempt to provide water for basic needs to all South Africans, while safeguarding sufficient water for ecosystems. To understand whether the system is heading on a resilient pathway, it is worth revisiting the three aspects of the moving target problem noted above and consider the policy lessons they offer for the new era of water management:

\section{Changing discourses and their inclusiveness}

The use of the frameworks underscores an important finding about changing water management discourses. A fundamental change from the first to second iteration is in managers' perception of what constitutes a desirable water management system and what the appropriate pathways might be to achieve it. Today, there is widespread agreement that the old system was unsustainable and needed reform, but opinion varies about which aspects of the new water policy demand highest priority (Pollard and du Toit 2005). Powerful players in the system may try to control agendas to achieve their own objectives, but may compromise a broader whole-of-system resilience. This raises an important question for future South African water management: will resilience necessarily be traded off between certain sectors of society, or scales, so that it can be achieved at another? If so, whose resilience counts more? These questions suggest that guiding water management through a diverse and multi-faceted knowledge system, as highlighted by Roux et al. (2006), will be critically important for resolving such trade-offs.

\section{Changing system boundaries and external connections}

In the first iteration of each framework, the system can essentially be described without including broader-scale regional or finer-scale local processes, because these received minimal consideration in the national system. During the second iteration, the awareness and influence of global and regional change increase, as does the involvement of local institutions and communities in decision making. Because cross-scale processes, e.g., climate change, international trade, interbasin transfers, shared management arrangements, are becoming more relevant to the system, in the coming years resilient pathways for water management will need to be identified at multiple scales and within a cross-scale governance system. This makes the need for the new CMAs and other institutions to coordinate their roles across scales especially pertinent.

\section{Lingering consequences of past management actions}

Both frameworks indicate that some options have been eliminated or constrained by previous management decisions, even as a new iteration begins, making only certain management pathways viable. This is at odds with the concept of resilient pathways, which seeks to maintain a range of options. Although ecological consequences of past actions have removed numerous options, e.g., restoration of heavily degraded catchments may be prohibitively costly; the social consequences of past actions are perhaps even more acute. As the past system denied many people adequate water supplies and the opportunity to use water productively, a real challenge faced in meeting the three principles is the tremendous backlog of water service provision and the great political pressure to remedy this as quickly as possible and at whatever cost necessary. This, however, may seriously jeopardize the achievement of the Water Act's sustainability principle (Turton and Meissner 2002). At the same time, opportunities should be sought in the negative consequences of past management decisions to achieve positive environmental and social outcomes, such as in the Working for Water Programme, a government initiative to simultaneously restore degraded catchments and relieve poverty by employing large numbers of individuals in alien plant clearing (Turpie 2004).

In using both frameworks, it becomes clear that the water management system contains two, if not more, distinct social subsystems, i.e., that of the previously advantaged (in most cases, White) and previously disadvantaged (in most cases, nonWhite). These two subsystems do not progress through the phases of the MA framework and adaptive cycle in the same fashion. In particular, the speed of change in access to water and its benefits differs: whereas the passage of the Water Act granted new rights to water to the previously 
disadvantaged population, and diminished some rights of the previously advantaged population, the reality on the ground suggests this is a slower process for the former. This raises questions concerning the implications of such a subsystem structure for resilience, especially when the subsystems are vastly different. Resilience theory might suggest that the progression of different subsystems through the framework phases at different speeds helps to maintain resilience because major phase shifts are staggered; alternatively, the crossing of a single threshold may have cascading effects that collapse the whole system (Kinzig et al. 2006). In addition, if one subsystem benefits from its particular trajectory and another does not, i.e., the system lacks equity, resilience may be eroded. Moreover, when new actors in a subsystem are brought into the bigger system more prominently, as was the case with the end of apartheid and the passage of the Water Act, they may not share responsibility for the consequences of past management actions, particularly when these actions have led to undesirable outcomes for them.

Achieving the water management vision is thus a challenging prospect, in part because, considering the points above: (1) discourses, even if inclusive, are subject to manipulation and power plays; (2) changing boundaries imply equity issues on a broader scale, for example, those involving poor users downstream but beyond South Africa's borders; and (3) past overallocation and poor management of water means that the playing field has been leveled at a lower level than that enjoyed by the previously advantaged.

The interactions between these key contextual changes and the SES structure need further investigation, which is not dealt with here. However, if these typically slower and more subtle contextual changes and structural issues are identified in the institutional and policy processes now being set up, the chances of achieving and sustaining a vision in the long term will increase.

\section{CONCLUSION}

Resilience concepts have begun to emerge in current South African water policy and research, but largely in a superficial context (however, see Funke et al. 2008, unpublished manuscript). The unprecedented transformation that is taking place in South Africa's water sector presents an excellent opportunity to test and contribute to resilience theory and application from a long-term perspective. For example, although the frameworks illustrate reasonably well the water management system thus far, interesting questions are raised as to whether the system will continue to pass through the phases described by the frameworks, and if not, how and why will it deviate? This analysis further highlights the challenge of assessing and enhancing resilience of largescale systems, in which distinct subpopulations follow different trajectories, or follow the same trajectory at different speeds. The South African example is particularly illuminating because of the social subsystem structure noted above, with different levels of privilege and rates of change in the processes that bestow privilege, which may bear on the ability to manage along resilient pathways. In the current era, new subsystems may form along different boundaries, such as CMA boundaries or different water user groups, and may continue to define an advantaged and disadvantaged population.

These characteristics are likely to be common in social-ecological systems (SES) across the world, and warrant future study. There is much international interest in operationalizing resilience definitions and frameworks (Cumming et al. 2005). The exercise above highlights the need to revisit definitions, continue applying frameworks, and adapting them to capture variations in SES. For those undertaking such efforts, an important consideration is that these frameworks are products of a western science paradigm that may be inaccessible to some users. For example, a research team in Peru who worked closely with Quechua communities found the Millennium Assessment framework too abstract, and modified it to better reflect local cosmologies (Zermoglio et al. 2006).

Finally, this analysis underscores the value of longer-term conceptualizations of resilience, which need to be supported with appropriate monitoring programs and data sets, and continued work involving disciplines that tend to conduct research on longer temporal scales.

Responses to this article can be read online at:

http://www.ecologyandsociety.org/voll3/iss 1/art19/responses/ 


\section{Acknowledgments:}

Belinda Reyers and Dirk Roux are thanked for helpful suggestions on the manuscript. This research was supported by the Millennium Ecosystem Assessment through a grant from the government of Norway, administered by the United Nations Environment Program. Additional institutional support was provided by the University of Pretoria, Stellenbosch University, and the Commonwealth Scientific and Industrial Research Organisation's Complex Systems Science Emerging Science Area and the Water for a Healthy Country National Research Flagship.

\section{LITERATURE CITED}

Allison, H. E., and R. J. Hobbs. 2004. Resilience, adaptive capacity, and the "Lock-in trap" of the Western Australian agricultural region. Ecology and Society 9(1):3. [online] URL: http://www.ecolo gyandsociety.org/vol9/iss1/art3.

Basson, M. S., P. H. van Niekerk, and J. A. van Rooyen. 1997. Overview of water resources and utilization in South Africa. Department of Water Affairs and Forestry (DWAF) report P RSA/00/0197, Pretoria, South Africa.

Berkes, F., J. Colding, and C. Folke, editors. 2003. Navigating social-ecological systems: building resilience for complexity and change. Cambridge University Press, Cambridge, UK.

Biggs, H. C., and K. H. Rogers. 2003. An adaptive system to link science, monitoring, and management in practice. Pages 59-80 in J. T. du Toit, K. H. Rogers, and H. C. Biggs, editors. The Kruger experience: ecology and management of savanna heterogeneity. Island Press, Washington, D.C., USA.

Bohensky, E., and T. Lynam. 2005. Evaluating responses in complex adaptive systems: insights on water management from the Southern African Millennium Ecosystem Assessment (SAfMA). Ecology and Society 10(1):11. [online] URL: http:/ /www.ecologyandsociety.org/vol10/iss1/art11/.
Carpenter, S. R., and M. G. Turner. 2001. Hares and tortoises: interactions of fast and slow variables in ecosystems. Ecosystems 3:495-497.

Carpenter, S. R., B. Walker, J. M. Anderies, and N. Abel. 2001. From metaphor to measurement: resilience of what to what? Ecosystems 4:765-781.

Cash, D. W., W. Adger, F. Berkes, P. Garden, L. Lebel, P. Olsson, L. Pritchard, and O. Young. 2006. Scale and cross-scale dynamics: governance and information in a multilevel world. Ecology and Society 11(2):8. [online] URL: http://www.ecology andsociety.org/vol11/iss2/art8/.

Chikozho, C. 2005. Policy and institutional dimensions of integrated river basin management: broadening stakeholder participatory processes in the Inkomati River Basin of South Africa and the Pangani River Basin of Tanzania. Commons southern Africa occasional paper series Number 12. Centre for Applied Social Sciences/Programme for Land and Agrarian Studies, Harare and Cape Town, South Africa.

Chutter, F. M., R.W. Palmer, and J. J. Walmsley. 1996. Environmental overview of the Orange River: Orange River development project replanning study. Department of Water Affairs and Forestry (DWAF) report PD 00/00/5295, Pretoria, South Africa.

Cumming, G. S., G. Barnes, S. Perz, M. Schmink, K. E. Sieving, J. Southworth, M. Binford, R. D. Holt, C. Stickler, and T. Van Holt. 2005. An exploratory framework for the empirical measurement of resilience. Ecosystems 8:975-987.

Cumming, G. S., and J. Collier. 2005. Change and identity in complex systems. Ecology and Society 10 (1):29. [online] URL: http://www.ecologyandsociety. org/vol10/iss1/art29/.

Cumming, G. S., D. H. M. Cumming, and C. L. Redman. 2006. Scale mismatches in socialecological systems: causes, consequences, and solutions. Ecology and Society 11(1): 14. [online] URL: http://www.ecologyandsociety.org/vol11/iss1/ $\underline{\operatorname{art14} / .}$

Dent, M. C. 2005. CMA Leadership Letter 37: capacity, skills, empowerment and delivery. University of KwaZulu-Natal, Pietermaritzburg, South Africa. 
Department of Water Affairs and Forestry (DWAF). 2003. Hydrological information system. Department of Water Affairs and Forestry, Pretoria South Africa. Available online at: http://www.dwaf. gov.za/hydrology/cgi-bin/his/cgihis.exe/station.

Department of Water Affairs and Forestry (DWAF). 2004a. National water resources strategy. First edition. DWAF, Pretoria, South Africa.

Department of Water Affairs and Forestry (DWAF). 2004b. A decade of delivery. DWAF, Pretoria, South Africa. Available online at: http://w ww.dwaf.gov.za/Communications/Articles/Kasrils/2004/ TEN\%20YEARS\%200F\%20DELIVER\%20ARTICLE. doc.

Department of Water Affairs and Forestry (DWAF). 2007. Water services national information system. Department of Water Affairs and Forestry (DWAF), Pretoria, South Africa. Available online at: http://www.dwaf.gov.za/dir ws/WSNIS/index.asp? $\mathrm{fa}=$ homepage.homepage\&curPerspectiveID $=2 \& \mathrm{cu}$ $\underline{\text { rNavViewID }=0 \text {. }}$.

Falkenmark, M. 2003. Freshwater as shared between society and ecosystems: from divided approaches to integrated challenges. Philosophical Transactions of the Royal Society of London Series $B$ 358:2037-2049.

Folke, C. 2003. Freshwater for resilience: a shift in thinking. Philosophical Transactions of the Royal Society of London Series B 358:2027-2036.

Folke, C., L. Pritchard, F. Berkes, J. Colding, and U. Svedin. 2007. The problem of fit between ecosystems and institutions: ten years later. Ecology and Society 12(1):30. [online] URL: http://www.ec ologyandsociety.org/vol12/iss1/art30/.

Görgens, A. H. M., and B.W. van Wilgen. 2004. Invasive alien plants and water resources in South Africa: current understanding, predictive ability and research challenges. South African Journal of Science 100:27-33.

Gunderson, L. H., and C. S. Holling, editors. 2002. Panarchy: understanding transformations in human and natural systems. Island Press, Washington, D.C., USA.

Haupt, C. J. 2001. Water resources situation assessment: groundwater resources of South Africa. Department of Water Affairs and Forestry, Pretoria, South Africa.

Herold, C. E., A. Görgens, and H. R. van Vliet. 1992. The influence of atmosphere deposition on the Vaal Dam. In: Proceedings of the Water Week Conference, Pretoria, South Africa.

Holling, C. S. 1986. The resilience of terrestrial ecosystems; local surprise and global change. Pages 292-317 in W. C. Clark and R. E. Munn, editors. Sustainable development of the biosphere. Cambridge University Press, Cambridge, UK.

Holling, C. S. 1987. Simplifying the complex: the paradigms of ecological function and structure. European Journal of Operational Research 30:139-146. Republished 1995 in Futures 26:598-609.

Holling, C. S. 2001. Understanding the complexity of economic, social and ecological systems. Ecosystems 4:390-405.

Holling, C. S., and L. H. Gunderson. 2002. Resilience and adaptive cycles. Pages 25-62 in L. H. Gunderson and C. S. Holling, editors. Panarchy: understanding transformations in human and natural systems. Island Press, Washington, D.C., USA.

Holling, C. S., and L. H. Gunderson, and G. D. Peterson. 2002. Sustainability and panarchies. Pages 63-102 in L. H. Gunderson and C. S. Holling, editors. Panarchy: understanding transformations in human and natural systems. Island Press, Washington, D.C., USA.

Janssen, M. A, T. A. Kohler, and M. Scheffer. 2003. Sunk-cost effects and vulnerability to collapse in ancient societies. Current Anthropology 44(5):722-728.

Kalikoski, D. C., M. Vasconcellos, and L. Lavkulich. 2002. Fitting institutions to ecosystems: the case of artisanal fisheries management in the estuary of Patos Lagoon Marine Policy 26:179-196.

King, J., and C. Brown. 2006. Environmental flows: striking the balance between development and resource protection. Ecology and Society 11 (2):26. [online] URL: http://www.ecologyandsociety. org/vol11/iss2/art26/. 
Kinzig, A. P., P. Ryan, M. Etienne, H. Allison, T. Elmqvist, and B. H. Walker. 2006. Resilience and regime shifts: assessing cascading effects. Ecology and Society 11(1):20. [online] URL: http://www.ec ologyandsociety.org/vol11/iss1/art20/.

Kleynhans, C. J. 2000. Desktop estimates of the ecological importance and sensitivity categories (EISC), default ecological management classes (DEMC), present ecological status categories (PESC), present attainable ecological management classes (present AEMC), and best attainable ecological management class (best AEMC) for quaternary catchments in South Africa. DWAF report. Institute for Water Quality Studies, Pretoria, South Africa.

Le Maitre, D., D. M. Richardson, and R. A. Chapman. 2004. Alien plant invasions in South Africa: driving forces and the human dimension. South African Journal of Science 100:103- 112.

Ludwig, J. A., and M. D. Stafford Smith. 2005. Interpreting and correcting cross-scale mismatches in resilience analysis: a procedure and examples from Australia's rangelands. Ecology and Society 10(2):20. [online] URL: http://www.ecolog yandsociety.org/vol10/iss2/art20/.

Millennium Ecosystem Assessment (MA). 2003. Ecosystems and human well-being: a framework for assessment. A report of the Conceptual Framework Working Group of the Millennium Ecosystem Assessment. Island Press, Washington, D.C., USA.

Millennium Ecosystem Assessment (MA). 2005. Ecosystems and human well-being: synthesis. Island Press, Washington, D.C. Available online at: http://www.millenniumassessment.org/.

Macleod, F. 2006. "Damned from the start." Mail and Guardian, 3-9 February 2006, Johannesburg, South Africa.

MacKay, H. M. 2003. Water policies and practices. Pages 49-83 in D. Reed and M. de Wit, editors. Towards a just South Africa: the political economy of natural resource wealth. WWF Macroeconomics Programme Office, Washington D.C., USA and CSIR, Pretoria, South Africa.

MacKay, H. M., K. H. Rogers, and D. J. Roux. 2003. Implementing the South African water policy: holding the vision while exploring an uncharted mountain. Water SA 29(4):353-358.

Metsi Consultants. 2002. Lesotho Highlands water project final report: summary of main findings for phase I. Development Report No. LHDA-678F-001.

Moench, M. 2005. Water, climatic variability and livelihood resilience: concepts, field insights and policy implications. Policy Paper II by The Resilience and Freshwater Initiative, Swedish Water House, Stockholm, Sweden.

Myburgh, E., and E. M. Nevill. 2003. Review of blackfly (Diptera: Simuliidae) control in South Africa. Onderstepoort Journal of Veterinary Research 70:307-317.

Nel, J., G. Maree, D. Roux, J. Moolman, N. Kleynhans, M. Silberbauer, and A. Driver. 2004. South African National Spatial Biodiversity Assessment 2004: Technical Report. Volume 2: River Component. CSIR Report Number ENV-SI-2004-063. Stellenbosch: Council for Scientific and Industrial Research.

Palmer C. G., R. Berold, W. J. Muller, and P. A. Scherman. 2002. Some for all forever: water, ecosystems and people. WRC Report No TT176/02. Water Research Commission, Pretoria, South Africa.

Peterson, G. D. 2000. Political ecology and ecological resilience: an integration of human and ecological dynamics. Ecological Economics 35: 323-336.

Pollard, S., and D. du Toit. 2005. Achieving integrated water resource management: the mismatch in boundaries between water resources management and water supply. Paper presented at International workshop on 'African Water Laws: Plural Legislative Frameworks for Rural Water Management in Africa', 26-28 January 2005, Johannesburg, South Africa.

Pritchard, L., and S. E. Sanderson. 2002. The dynamics of political discourse in seeking sustainability. Pages 147-169 in L. Gunderson and C. S. Holling, editors. Panarchy: understanding transformations in human and natural Systems. Island Press, Washington D.C., USA.

Redman, C. L., and A. P. Kinzig. 2003. Resilience 
of past landscapes: resilience theory, society, and the longue durée. Conservation Ecology 7(1):14. [online] URL: http://www.consecol.org/vol7/iss1/art14

Rogers, K. H., and R. Bestbier. 1997. Development of a protocol for the definition of the desired state of riverine systems in South Africa. Department of Environmental Affairs and Tourism, Pretoria, South Africa. Available online at: http://www.ngo.grida. no/soesa/nsoer/resource/wetland/abstract_protocol. htm.

Rogers, K., and H. C. Biggs. 1999. Integrating indicators, endpoints and value systems in strategic management of the rivers of the Kruger National Park South Africa. Freshwater Biology 41:439-452.

Rogers, K., D. Roux, and H. Biggs. 2000. The value of visions and art of visionaries. Conservation Ecology 4(1):11. [online] URL: http://www.consecol. org/vol4/iss1/resp1.

Roux, D. J., K. H. Rogers, H. C. Biggs, P. J. Ashton, and A. Sergeant. 2006. Bridging the science- management divide: moving from unidirectional knowledge transfer to knowledge interfacing and sharing. Ecology and Society 11 (1):4. [online] URL:http://www.ecologyandsociety. org/vol11/iss 1/art4/.

Scheffer, M., S. Carpenter, J. A. Foley, C. Folke, and B. Walker. 2001. Catastrophic shifts in ecosystems. Nature 413:591-596.

Seetal, A. 2005. Progress with water allocation reform in South Africa. Paper presented at OECD workshop on Agriculture and water: sustainability, markets and policies. 14-18 November, 2005, Adelaide, Australia.

Snaddon, C. D., M. J. Wishart, and B. R. Davies. 1998. Some implications of inter-basin water transfers for river ecosystem functioning and water resources management in southern Africa. Journal of Aquatic Ecosystem Health and Management 1:159-162.

Thabane, M. 2000. Shifts from old to new social ecological environments in the Lesotho Highlands water scheme; relocating residents of the Mohale Dam area. Journal of Southern African Studies 26 (4):633-654.

Thompson, H., C. M. Stimie, E. Richters, and S.
Perret. 2001. Policies, legislation and organizations related to water in South Africa, with special reference to the Olifants River basin. Working Paper 18. South Africa Working Paper No. 7. International Water Management Institute, Columbo, Sri Lanka.

Tompkins, E. L., and W. N. Adger. 2004. Does adaptive management of natural resources enhance resilience to climate change? Ecology and Society 9(2):10. [online] URL: http://www.ecologyandsociety. org/vol9/iss 2/art10/.

Turpie, J. 2004. The role of resource economics in the control of invasive alien plants in South Africa. South African Journal of Science 100:87-93.

Turton, A. R. 2003. The hydropolitical dynamics of cooperation in southern Africa: a strategic perspective on institutional development in international river basins. African Water Issues Research Unit, Pretoria, South Africa.

Turton, A., R., H. Hattingh, M. Claassen, D. Roux, and P. Ashton. 2005. Towards a model for ecosystem governance: an integrated water resource management example. CSIR-Environmentek, Pretoria, South Africa.

Turton, A. R., and R. Henwood, editors. 2002. Hydropolitics in the developing world: a southern African perspective. African Water Issues Research Unit, Pretoria, South Africa.

Turton, A. R., and R. Meissner. 2002. The hydrosocial contract and its manifestation in society: A South African case study. Pages 37-60 in A. R. Turton and R. Henwood, editors. Hydropolitics in the developing world: a southern African perspective. African Water Issues Research Unit, Pretoria, South Africa.

van der Leeuw, S. E., and C. Aschan-Leygonie. 2001. A long-term perspective on resilience in socio-natural systems. Working Paper No. 01-08-042, Santa Fe Institute, Santa Fe, California, USA.

Walker, B., S. Carpenter, J. Anderies, N. Abel, G. Cumming, M. Janssen, L. Lebel, J. Norberg, G. D. Peterson, and R. Pritchard. 2002. Resilience management in social-ecological systems: a working hypothesis for a participatory approach. Conservation Ecology 6(1): 14. [online] URL: http ://www.consecol.org/vol6/iss1/art14/. 
Walker, B. H., L. H. Gunderson, A. P. Kinzig, C. Folke, S. R. Carpenter, and L. Schultz. 2006. A handful of heuristics and some propositions for understanding resilience in social-ecological systems. Ecology and Society 11(1):13. [online] URL: http://www.ecologyandsociety.org/vol11/iss1/ art13/.

Walker, B., and J. A. Meyers. 2004. Thresholds in ecological and social-ecological systems: a developing database. Ecology and Society 9(2):3. [online] URL: http://www.ecologyandsociety.org/vol9/ iss2/art3.

Wilson, J. A. 2006. Matching social and ecological systems in complex ocean fisheries. Ecology and Society 11(1):9. [online] URL:http://www.ecologya ndsociety.org/vol11/iss1/art9/.

Wilson, J. A., B. Low, R. Costanza, and E. Ostrom. 1999. Scale misperceptions and the spatial dynamics of a social-ecological system. Ecological Economics 31:243-257.

Wolfenden, J., M. Evans, D. Essaw, F. Johnson, A. Sanderson, G. Starkey, and B. Wilkinson. 2007. Resilience management: a guide for irrigated regions, communities and enterprises. Cooperative Research Centre for Irrigation Futures, Technical Report No. 01/07, Sydney, Australia.

World Commission on Dams (WCD). 2000. Orange River development project, South Africa case study. Prepared as an input to the World Commission on Dams, Cape Town, South Africa. Available online at: http://www.dams.org.

World Resources Institute (WRI). 2000. World resources 2000-2001: people and ecosystems: the fraying web of life. World Resources Institute, Washington, D.C., USA.

Zermoglio, M. F., A. S., Van Jaarsveld, W. V. Reid, J. Romm, R. Biggs, Y. Tianxiang, and L. Vicente. 2006. The multiscale approach. Pages 61-83 in D. Capistrano, M. Lee, C. Raudsepp-Hearne, and C. Samper, editors. Findings of the Sub-global Assessments Working Group of the Millennium Ecosystem Assessment. Volume 4. Ecosystems and human well-being: multiscale assessments. Island Press, Washington, D.C., USA. 